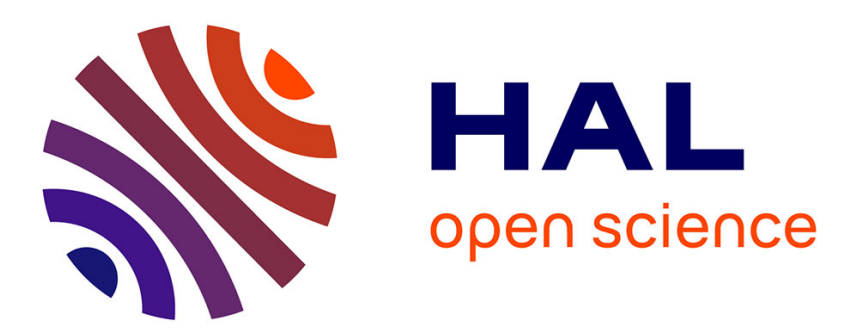

\title{
Investigation of interface erosion rate by Jet Erosion Test and statistical analysis
}

Pierre-Louis Regazzoni, Didier Marot

\section{To cite this version:}

Pierre-Louis Regazzoni, Didier Marot. Investigation of interface erosion rate by Jet Erosion Test and statistical analysis. European Journal of Environmental and Civil Engineering, 2011, 15 (8), pp.1167-1185. 10.3166/EJECE.15.1167-1185 . hal-01006999

\section{HAL Id: hal-01006999 \\ https://hal.science/hal-01006999}

Submitted on 10 Mar 2018

HAL is a multi-disciplinary open access archive for the deposit and dissemination of scientific research documents, whether they are published or not. The documents may come from teaching and research institutions in France or abroad, or from public or private research centers.
L'archive ouverte pluridisciplinaire HAL, est destinée au dépôt et à la diffusion de documents scientifiques de niveau recherche, publiés ou non, émanant des établissements d'enseignement et de recherche français ou étrangers, des laboratoires publics ou privés. 


\title{
Investigation of interface erosion rate by Jet Erosion Test and statistical analysis
}

\section{Pierre-Louis Regazzoni - Didier Marot}

\author{
Institut de Recherche en Génie Civil et Mécanique \\ Université de Nantes/CNRS \\ 58, rue Michel Ange \\ F-44606 Saint-Nazaire Cedex \\ didier.marot@univ-nantes.fr
}

\begin{abstract}
Erosion is one of the main causes of instabilities within hydraulic earth structures. Two types of erosion can be distinguished: suffusion and interface erosion. This paper deals with the interface erosion phenomenon and the Jet Erosion Test is used in order to evaluate the erodibility of fine soils. A new energy analysis of the test is developed, relating the total eroded mass to the dissipated fluid energy. A new erosion resistance index is proposed. The erodibility is evaluated for twelve natural soil specimens which are compacted with the Proctor protocol. They represent a large range of erosion sensitivity. A wide dissipated hydraulic energy scale appears and a statistical analysis is carried out which gives a correlation of the erosion resistance index with three physical parameters.
\end{abstract}

RÉSUMÉ. L'érosion est l'une des principales causes d'instabilités d'ouvrages hydrauliques en terre. Deux types d'érosion peuvent être distingués : la suffusion et l'érosion d'interface. Cet article porte sur l'érosion d'interface et le Jet Erosion Test est utilisé afin d'évaluer la sensibilité à l'érosion de sols fins. Une nouvelle analyse énergétique de l'essai est développée qui relie la masse totale érodée avec l'énergie dissipée par le fluide. Un nouvel indice de résistance à l'érosion est proposé. La sensibilité à l'érosion est évaluée pour douze sols naturels qui sont compactés suivant le protocole Proctor et qui représentent une large gamme de sensibilité à l'érosion. Une large gamme d'énergie est mise en évidence et l'analyse statistique qui est menée permet d'exprimer une corrélation entre l'indice de résistance à l'érosion et trois paramètres physiques.

KEYWORDS: soil erosion, JET, cohesive soils, energy, statistical analysis, water flow, dynamic compaction.

MOTS-CLÉS : érosion, JET, sols cohésifs, énergie, analyse statistique, écoulement, compactage dynamique. 


\section{Introduction}

Internal erosion is one of the main causes of instabilities within hydraulic earth structures such as dams, dikes or levees (Foster et al., 2000). The mechanisms of internal erosion are very complex and involve many parameters, some of which are coupled. In earth structures and their foundations, two types of internal erosion processes can be distinguished: suffusion and interface erosion. Suffusion process concerns only the finer particles which are detached and move inside the soil matrix constituted by the coarse particles. Interface erosion can appear in cracks or concentrated leaks and is then called piping. When the interface erosion appears between two materials having different grain size distributions, it is called contact erosion. However this interface, relatively large compared to the grain scale, can also be located between soil and water. In such case and with a seepage flow which is normal to the interface, process is called backward erosion (Fell and Fry, 2007).

Several testing devices for studying the interface erosion of fine grained soils were proposed by various researchers. These tests apply hydraulic stresses to a soil sample by a variety of methods. In literature, the interpretations of the experiments are based on a linear erosion law stating that the mass rate of erosion, $\dot{m}$, or the volumetric rate of erosion, $\dot{\varepsilon}$, is proportional to the excess hydraulic shear stress $\tau$ above a threshold value $\tau_{\mathrm{c}}$ which represents the minimal hydraulic shear stress needed to initiate erosion. In equation form, the erosion laws are:

$$
\begin{aligned}
& \dot{m}=k_{d, m}\left(\tau-\tau_{C}\right) \\
& \dot{\varepsilon}=k_{d}\left(\tau-\tau_{C}\right)
\end{aligned}
$$

with $\mathrm{k}_{\mathrm{d}, \mathrm{m}}$ and $\mathrm{k}_{\mathrm{d}}$ : erosion rate coefficients, with $\mathrm{k}_{\mathrm{d}, \mathrm{m}}=\mathrm{k}_{\mathrm{d}} \rho_{\mathrm{D}}$ where $\rho_{\mathrm{D}}$ : soil dry density.

One of these main devices is the Hole Erosion Test apparatus (HET) which was developed by Wan and Fell (2004). HET can be performed on a Proctor mould containing the soil specimen. A $6.35 \mathrm{~mm}$ diameter hole is pre-drilled through the centreline-axis to simulate a concentrated leak. A constant hydraulic head is applied to the specimen. The data collected during test are the head losses across the sample and the flow rate. When erosion is produced, the resulting increase of flow rate is used to estimate the increase of the hole diameter and thus to determine the resulting mass rate of erosion.

Thanks to the values of diameter (representing the erosion), with the Wan and Fell (2004)'s method or with the scaling law proposed by Bonelli and Brivois (2008), it is possible to determine the value of the erosion rate coefficient and the value of critical shear stress.

Wan and Fell (2004) proposed a classification of internal erosion risk based on the value of erosion rate index determined from HET results and defined by: 


$$
I_{H E T}=-\log _{10}\left(k_{d, m}\right)
$$

Wan and Fell described the erosion development by defining six groups, varying from extremely slow to extremely rapid.

Hanson and Cook (2004) developed the submerged Jet Erosion Test (JET). This apparatus is designed to apply a submerged jet on the soil surface and it allows performing in-situ tests. The depth of scour beneath the jet is measured over time and the hydraulic stress on the soil surface decreases as scour occurs. Hanson and Cook assumed that the equilibrium depth is reached when the stress at the interface is equal to the threshold stress. The erosion never stops but the erosion speed is decreasing and the hydraulic shear stress is converging asymptotically to the threshold stress. By fitting scour measurements and time data on an asymptotic function, the equilibrium depth and the corresponding critical stress are deduced. The experimental data are fitted to the calculated scour depth. This yields an estimate of the detachment rate coefficient, $\mathrm{k}_{\mathrm{d}}$.

The soil erodibility classification proposed by Hanson and Simon (2001) is based on both the critical shear stress and the erosion rate coefficient determined from JETs. This classification recognizes five categories from very resistant to very erodible materials.

For the comparison of the two apparatuses, seven natural occurring fine-grained soils, covering a large range of erodibility were tested (Regazzoni et al., 2008). Soils were compacted according to normal Proctor procedure and with an initial water content equal to the optimum water content less one percent. It was shown that by using the commonly used methods, the values of the erosion coefficient are systematically higher with the JET than with the HET and the corresponding mean rate index is systematically smaller with the JET $\left(\mathrm{I}_{\mathrm{JET}}\right)$ than with the HET $\left(\mathrm{I}_{\mathrm{HET}}\right)$. The $\mathrm{I}_{\mathrm{JET}} / \mathrm{I}_{\mathrm{HET}}$ ratio varies from 0.32 to 0.84 . On average, the HET critical shear stress is about fifty times higher than the JET critical shear stress. Moreover the relative soils classifications yielded by the two erodimeters are not exactly the same (Regazzoni, 2009). Marot et al. (2011) proposed an energy analysis and a new erosion resistance index was defined. Using the energy analysis, an identical soil classification was built with the two devices and six categories of soil erodibility were proposed from very resistant to very erodible.

This paper deals with the relationship between surface erosion properties and other soil properties in a large range of erosion sensitivity. The erodibility was evaluated for twelve natural soils. The Jet Erosion Test was used and the results were interpreted by the energy method.

A large range of dissipated hydraulic energy appears, and a statistical analysis was carried out which gives an expression of the erosion resistance index with several physical parameters. 


\section{Erosion device and energy analysis of tests}

\subsection{Principle of Jet Erosion Test}

Figure 1 presents the principle of the device. The jet test apparatus consists of an adjustable head tank, a jet tube with a nozzle, a point gage and a jet submerged tank which contains the specimen. The point gage is adjusted to close off the nozzle and also to measure the depth of scour below the nozzle.

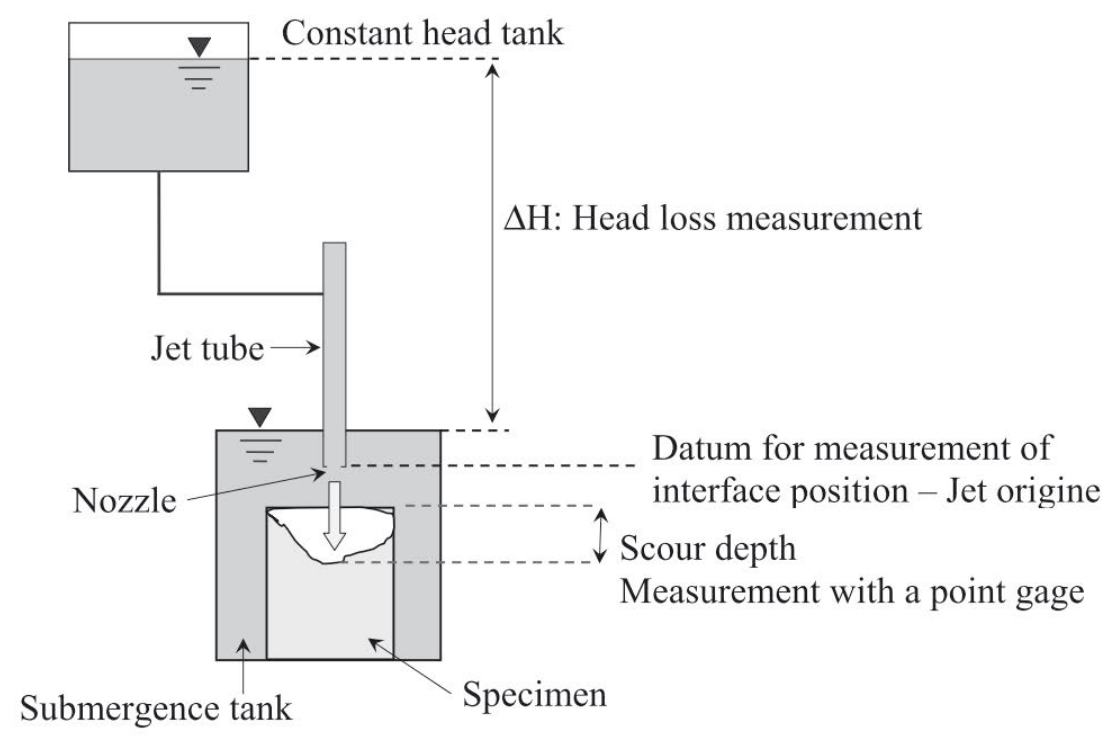

Figure 1. Principle of Jet Erosion Test

The jet tube is mounted to the submergence tank cover so that the height of the nozzle above the soil surface (distance $\mathrm{J}_{0}$ on Figure 2) can be adjusted to different heights prior to the start of a test. The jet tube and cover can also be mounted to a heavy-duty field tank for in situ measurements. The jet is typically oriented vertically, but when the test is performed on a slope, it can also be positioned at an angle.

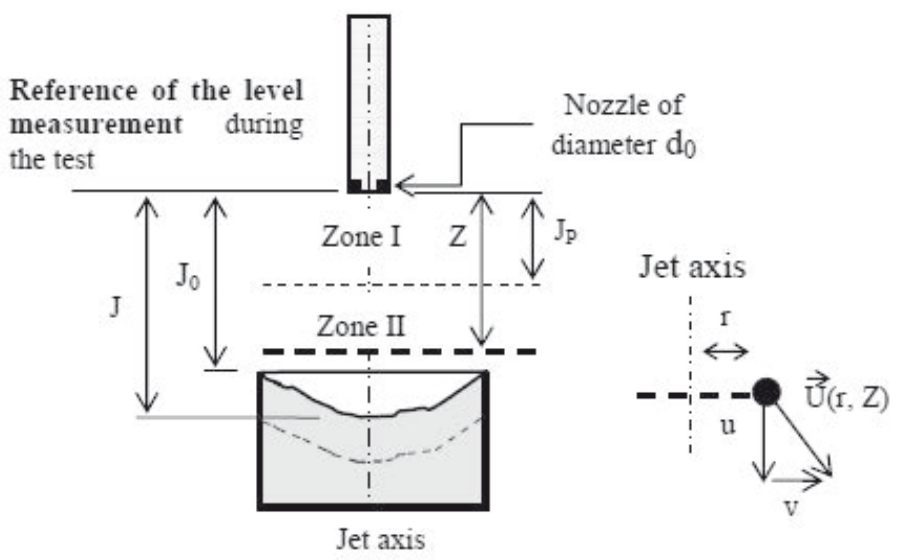

Figure 2. Different measurements during Jet Erosion Test 
The collected data during the test at specific times include: the depth of scour J measured from a reference level and the head loss between the top of the constant head tank and the top of the submerged tank, $\Delta \mathrm{H}$. Data are recorded at intervals chosen by the operator, depending on the erosion rate. Typical intervals range from $15 \mathrm{~s}$ to $30 \mathrm{~min}$, with total test times of 2 hours or less (Hanson and Cook, 2004). With these data, it is possible to relate the hydraulic conditions at interface to the erosion rate at a time $t$.

\subsection{Water velocity}

With the objective to evaluate the water velocity in the area of the impact, three zones are defined in conformity with Hanson and Cook (2004)'s analysis (see Figure 2). In the zone I (altitude $\mathrm{Z}<\mathrm{J}_{\mathrm{P}}=6.2 \mathrm{~d}_{0}$, with $\mathrm{d}_{0}$ : diameter of the jet at the exit), the water velocity on the axis is constant and equal to the initial velocity at the jet origin $\mathrm{u}(0,0)$. In the zone II $\left(\mathrm{Z}>\mathrm{J}_{\mathrm{P}}\right)$ and far from the interface $(\mathrm{Z}<0.86-0.9 \mathrm{~J}$, with J: distance between soil-water interface and jet origin), the axial velocity is proportional to the inverse value of the distance between the jet origin and the altitude considered:

$$
u(0, Z)=u(0,0) \frac{J_{p}}{Z}
$$

In the zone near the interface $(\mathrm{J}>\mathrm{Z}>0.9-0.86 \mathrm{~J})$, the vertical velocity at a distance $r$ from the jet axe and a distance $Z$ from the jet origin $(u(r, Z))$ decreases to 0 to be converted into radial velocity (v(r, Z)). Beltaos and Rajaratnam (1974) conducted tests of impinging circular turbulent jet and they proposed an expression of the vertical velocity on the jet axis:

$$
\frac{u(r, Z)}{u(0, Z)}=\exp \left(-0.693\left(\frac{r}{b_{u}}\right)^{2}\right)
$$

where $\mathrm{u}(0, \mathrm{Z})$ : water velocity at the distance $\mathrm{Z}$ from the jet origin on the jet axis in the case of a free jet; $b_{u}$ : distance from the axis where the water velocity on the axis is divided by two, $b_{u}=0.093\left(J-J_{P}\right)$.

\subsection{Energy analysis}

Regazzoni (2009) and Marot et al. (2011) proposed a method of interpretation based on the energy dissipation between the fluid and the soil. The main issue is to characterize independently the hydraulic loading and the induced erosion; these 
characterizations have to be based on measurements and associated with the minimum number of assumptions. The energy equation for the fluid (neglecting the soil phase inside the volume) can be written as:

$$
\begin{aligned}
& \frac{\mathrm{dE}}{\mathrm{dt}}=\frac{\mathrm{d}}{\mathrm{dt}} \iiint \int_{\text {Mass }}\left(\mathrm{e}_{\text {int }}+\frac{\mathrm{u}^{2}}{2}+\overrightarrow{\mathrm{g}} \cdot \overrightarrow{\mathrm{x}}\right) \cdot \mathrm{dM} \\
& =\frac{\partial}{\partial t} \underset{\text { Volume }}{\iiint_{\text {int }}}\left(e^{2}+\vec{g} \cdot \vec{x}\right) \cdot \rho_{W} d V+\oiint_{S}\left(e_{\text {int }}+\frac{u^{2}}{2}+\vec{g} \cdot \vec{x}\right) \cdot \rho_{W} \cdot(\vec{U} \cdot \vec{n}) \cdot d S
\end{aligned}
$$

where M: fluid mass, $\mathrm{V}$ : fluid volume, $\mathrm{e}_{\text {int }}$ : internal energy, $\mathrm{S}$ : interface between fluid and environment, n: normal vector of interface, $U$ : fluid velocity (components: $u, v, w$ ), $\mathrm{g}$ : gravity, $\rho_{\mathrm{w}}$ : fluid density, $\mathrm{x}$ : coordinates.

Total energy is the sum of the mechanical work $\mathrm{W}$ and the energy exchange between the system and the environment $\mathrm{E}_{\text {Ther }}$ :

$$
\frac{d E}{d t}=\frac{d E_{T h e r}}{d t}+\frac{d W}{d t}
$$

The whole experimental system is placed in a temperature controlled laboratory and it is supplied by the public water system. Thus for test duration, the system can be considered isothermal in time and internal energy is assumed constant. All tests are performed under the same experimental conditions, so the comparison of tests leads to neglect the relative variations of energy exchange between the system and the environment. In consequence the term $\mathrm{dE}_{\mathrm{Ther}} / \mathrm{dt}$ is negligible. As jet test results are analyzed in steady state (assuming during a time step that the water speed evolves slowly), the unsteady term of the kinetic energy is negligible. Finally the Equation [6] becomes:

$$
\frac{d W}{d t}=\oiint_{S}\left(\frac{u^{2}}{2}+\vec{g} \cdot \vec{x}\right) \rho_{w}(\vec{U} \cdot \vec{n}) \cdot d S
$$

The mechanical work $\mathrm{W}$ is the sum of: work done by pressure, viscous work in the fluid and work by erosion:

$$
\frac{d W_{\text {pressure }}}{d t}+\frac{d W_{\text {viscous in fluid }}}{d t}+\frac{d W_{\text {erosion }}}{d t}=\oiint_{S}\left(\frac{u^{2}}{2}+\vec{g} \cdot \vec{x}\right) \cdot \rho_{w} \cdot(\vec{U} \cdot \vec{n}) \cdot d S
$$

In comparison with free jet, jet in front of a soil-water interface is subjected to a deviation from the centreline. It is assumed that the erosion is mainly associated with this deviation which induces an increase of shear stress and a great variation of pressure. 
In front of a wall, Beltaos and Rajaratnam (1974) observed that wall shear stress increases linearly with lateral distance from jet centreline up to a maximum value obtained for $\mathrm{r}=0.14 \mathrm{~J}$ and then decreases with any further increase in $\mathrm{r}$. Moreover, when $\mathrm{r} / \mathrm{J}$ ratio increases from 0 to 0.14 , wall pressure decreases rapidly reaching $10 \%$ of maximum value of stagnation pressure on jet centreline axis. Thus at $J$ depth, erosion energy is assumed to come from the space defined by lateral distance from jet centreline $\mathrm{r} \leq 0.14 \mathrm{~J}$.

With the objective to take into account the variation of vertical velocity with the $J$ altitude and with the distance $r$ from the jet axe considered, Equations [9] and [5] are combined to express the temporal derivative of mechanical work through erosion by:

$$
\frac{d W_{\text {ersion }}}{d t}=2 \pi \int_{0}^{0.14 J} \frac{u^{2}}{2} \rho_{w}(\vec{U} \cdot \vec{n}) r d r=\pi \int_{0}^{0.14 J} \rho_{w} u^{3}(0, J)\left(\exp \left(-0.693\left(\frac{r}{b_{u}}\right)^{2}\right)\right)^{3}
$$

For convenience, the temporal derivative mechanical work by erosion is named erosion power $\left(\mathrm{P}_{\text {erosion }}\right)$.

To classify the soil according to the erosion, an erosion coefficient is proposed:

$$
\alpha=\frac{\dot{m}_{d r y}}{P_{\text {erosion }}}
$$

where, $\dot{m}_{d r y}$ rate of eroded dry mass.

The energy dissipated by erosion ( $\mathrm{E}_{\text {erosion }}$ ) is the time integration of the instantaneous erosion power for the test duration. Thus for each test, the erosion energy is computed by trapezoidal rule and the erosion resistance index is built with the erosion energy and the cumulative eroded dry mass $\left(\mathrm{m}_{\text {dry }}\right)$ :

$$
I_{\alpha}=-\log \left(\frac{m_{d r y}}{E_{\text {erosion }}}\right)
$$

According to values of erosion resistance index which were determined with both JET and HET devices, Marot et al. (2011) proposed six categories of soil erodibility: highly erodible for $\mathrm{I}_{\alpha}<1$, erodible for $1 \leq \mathrm{I}_{\alpha}<2$, moderately erodible for $2 \leq \mathrm{I}_{\alpha}<3$, moderately resistant for $3 \leq \mathrm{I}_{\alpha}<4$, resistant for $4 \leq \mathrm{I}_{\alpha}<5$ and highly resistant for $\mathrm{I}_{\alpha} \geq 5$. 


\section{Experimental investigation}

\subsection{Soils properties and testing program}

Twelve soils were selected (see Table 1), covering a large range of erodibility as determined by previous HET investigations (Regazzoni, 2009). The testing program concerns 8 natural soils, 2 soils were created on the basis of natural soils and 2 soils were created using industrial soil materials. A non plastic soils is considered to have a liquid limit and a plastic limit equal and with a value of about 0 . The values of optimal dry density for the normal Proctor compaction are ranging between $1378 \mathrm{~kg} / \mathrm{m}^{3}$ and $1980 \mathrm{~kg} / \mathrm{m}^{3}$ for water content between $10 \%$ and $24 \%$.

Table 1. Classification and properties of soils tested

\begin{tabular}{|c|c|c|c|c|c|}
\hline \multirow[b]{2}{*}{$\begin{array}{c}\text { Soil } \\
\text { reference } \\
\text { in paper }\end{array}$} & \multirow[b]{2}{*}{$\begin{array}{c}\text { USCS } \\
\text { classification }\end{array}$} & \multicolumn{2}{|c|}{ Atterberg limits } & \multicolumn{2}{|c|}{ Normal Proctor state } \\
\hline & & $\begin{array}{l}\text { Liquid } \\
\text { limit } \\
(\%)\end{array}$ & $\begin{array}{l}\text { Plasticity } \\
\text { index } \\
(\%)\end{array}$ & $\begin{array}{l}\text { Optimum } \\
\text { dry density } \\
\left(\mathrm{kg} / \mathrm{m}^{3}\right)\end{array}$ & $\begin{array}{c}\text { Optimum } \\
\text { water content } \\
\mathrm{w}_{\text {opt }}(\%)\end{array}$ \\
\hline $\mathrm{P} 2$ & ML & 21 & 4 & 1860 & 12 \\
\hline P3 & $\mathrm{CL}$ & 31 & 15 & 1900 & 13 \\
\hline $\mathrm{TE}$ & CL-ML & 29 & 4 & 1703 & 16 \\
\hline MF & $\mathrm{CL}$ & 47 & 34 & 1815 & 14 \\
\hline $\mathrm{TF}$ & $\mathrm{CH}$ & 55 & 40 & 1708 & 17 \\
\hline MP & $\mathrm{CH}-\mathrm{CL}$ & 54 & 31 & 1679 & 17 \\
\hline $\mathrm{BC}$ & $\mathrm{CH}$ & 69 & 44 & 1378 & 24 \\
\hline $\mathrm{L}$ & ML & \multicolumn{2}{|c|}{ Non plastic } & 1670 & 19 \\
\hline Mix 0 & $\mathrm{CL}$ & 44 & 23 & 1619 & 21 \\
\hline Mix 1 & $\mathrm{CL}$ & 34 & 11 & 1650 & 20 \\
\hline K50 S50 & $\mathrm{CL}$ & 30 & 13 & 1780 & 15 \\
\hline K20 S80 & ML & \multicolumn{2}{|c|}{ Non plastic } & 1980 & 10 \\
\hline
\end{tabular}

Notes: USCS $=$ Unified Soil Classification System.

Figure 3 shows that the soils are covering a large part of the Atterberg limits diagram.

The grain size distribution of each soil is described by four fractions: clay fraction $\mathrm{F}_{\text {clay }}$ (mass fraction in percentage of soil particles finer than $2 \mu \mathrm{m}$ ), silt 
fraction $\mathrm{F}_{\text {silt }}$ (mass fraction in percentage of soil particles between $2 \mu \mathrm{m}$ and $74 \mu \mathrm{m}$ ), fine sand fraction $\mathrm{F}_{\mathrm{fs}}$ (mass fraction of soil particles between $74 \mu \mathrm{m}$ and $425 \mu \mathrm{m}$ ) and coarse sand fraction $F_{c s}$ (mass fraction of soil particles coarser than $425 \mu \mathrm{m}$ ). The values of each fraction are given on Table 2 .

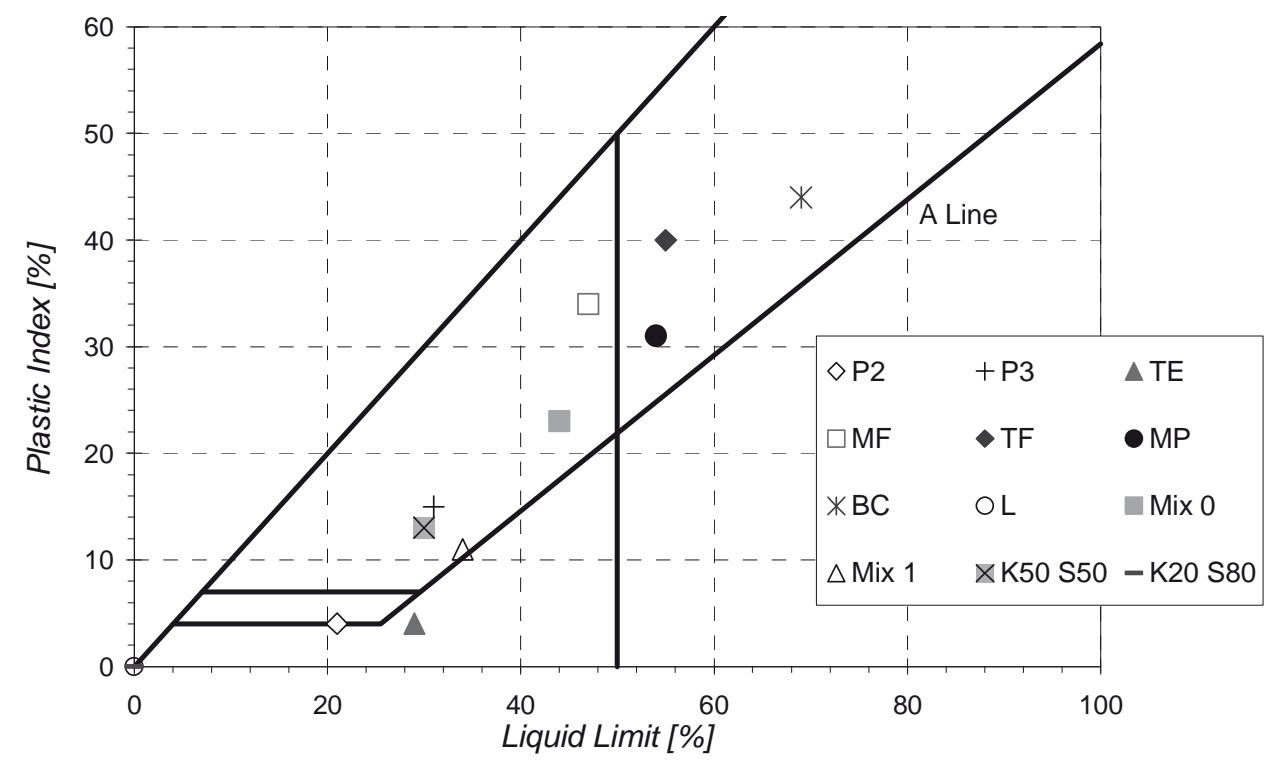

Figure 3. Casagrande diagram of soils tested

Table 2. Values of grain size distribution

\begin{tabular}{ccccc}
\hline $\begin{array}{c}\text { Soil } \\
\text { reference } \\
\text { in paper }\end{array}$ & $\begin{array}{c}\text { Clay fraction } \\
(\mathrm{d}<2 \mu \mathrm{m}) \\
(\%)\end{array}$ & $\begin{array}{c}\text { Silt fraction } \\
(2 \mu \mathrm{m}<\mathrm{d}<74 \mu \mathrm{m}) \\
(\%)\end{array}$ & $\begin{array}{c}\text { Fine sand fraction } \\
(74 \mu \mathrm{m}<\mathrm{d}<425 \mu \mathrm{m}) \\
(\%)\end{array}$ & $\begin{array}{c}\text { Coarse sand fraction } \\
(\mathrm{d}>425 \mu \mathrm{m}) \\
(\%)\end{array}$ \\
\hline P2 & 13.0 & 47.0 & 21.2 & 18.8 \\
P3 & 26.0 & 47.0 & 14.3 & 12.7 \\
TE & 10.9 & 76.6 & 9.4 & 3.1 \\
MF & 33.0 & 41.9 & 21.7 & 3.4 \\
TF & 42.3 & 51.4 & 5.5 & 0.8 \\
MP & 40.0 & 51.8 & 5.0 & 3.2 \\
BC & 65.9 & 30.5 & 1.8 & 1.8 \\
L & 6.8 & 92.2 & 0.7 & 0.3 \\
Mix 0 & 40.2 & 57.3 & 1.5 & 1.1 \\
Mix 1 & 21.8 & 76.6 & 0.5 & 1.1 \\
K50 S50 & 17.9 & 53.1 & 28.8 & 0.2 \\
K20 S80 & 12.1 & 35.8 & 51.9 & 0.3 \\
\hline
\end{tabular}


The preparation of the specimen is made according to the following procedures. First the natural soils are prepared, it means: a drying at $65^{\circ} \mathrm{C}$, the crushing and sieving with a \#4 A.S.T.M. sieve. For all tested soils, water is added and blended to target optimum water content less $1 \%$ (in conformity with procedure defined by USBR, 1987). The soil is let $36 \mathrm{~h}$ (at least) in a plastic bag. The compaction is made in three layers of 25 blows with a normal Proctor rammer. The specimen is let in a plastic bag for 12 hours before test performed by jet device.

\subsection{Results of testing}

Thirty eight tests were performed and the test duration was ranging from $1740 \mathrm{~s}$ to $6300 \mathrm{~s}$. Figure 4, plots the erosion power (maximum values between $0.04 \mathrm{~W}$ and $1.25 \mathrm{~W}$ ) in function of the scour depth (maximum values between $0.02 \mathrm{~m}$ and $0.11 \mathrm{~m}$ ). Based on this chart, a classification of erodibility of specimens can not be precisely established because the kinetic of the scour development is not taken into account and this characteristic can be very different for two tests. For example, during test TF-2, scour depth reaches $0.03 \mathrm{~m}$ in $75 \mathrm{~min}$ with associated erosion power $\mathrm{P}_{\text {erosion }}=0.11 \mathrm{~W}$, whereas only $2 \mathrm{~min}$ is sufficient to obtain the same order of magnitude for test TF-4.

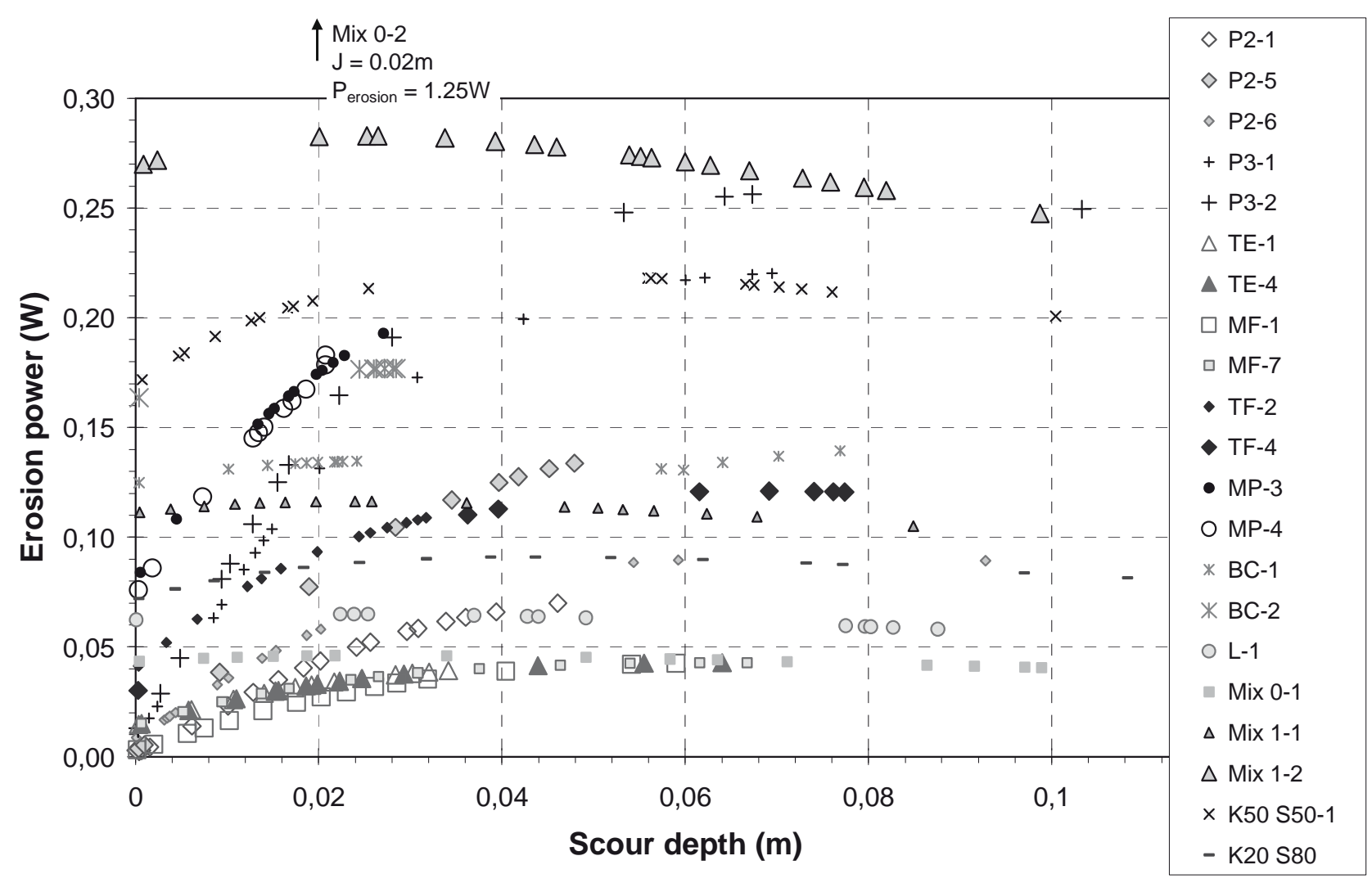

Figure 4. Erosion power in function of scour depth 


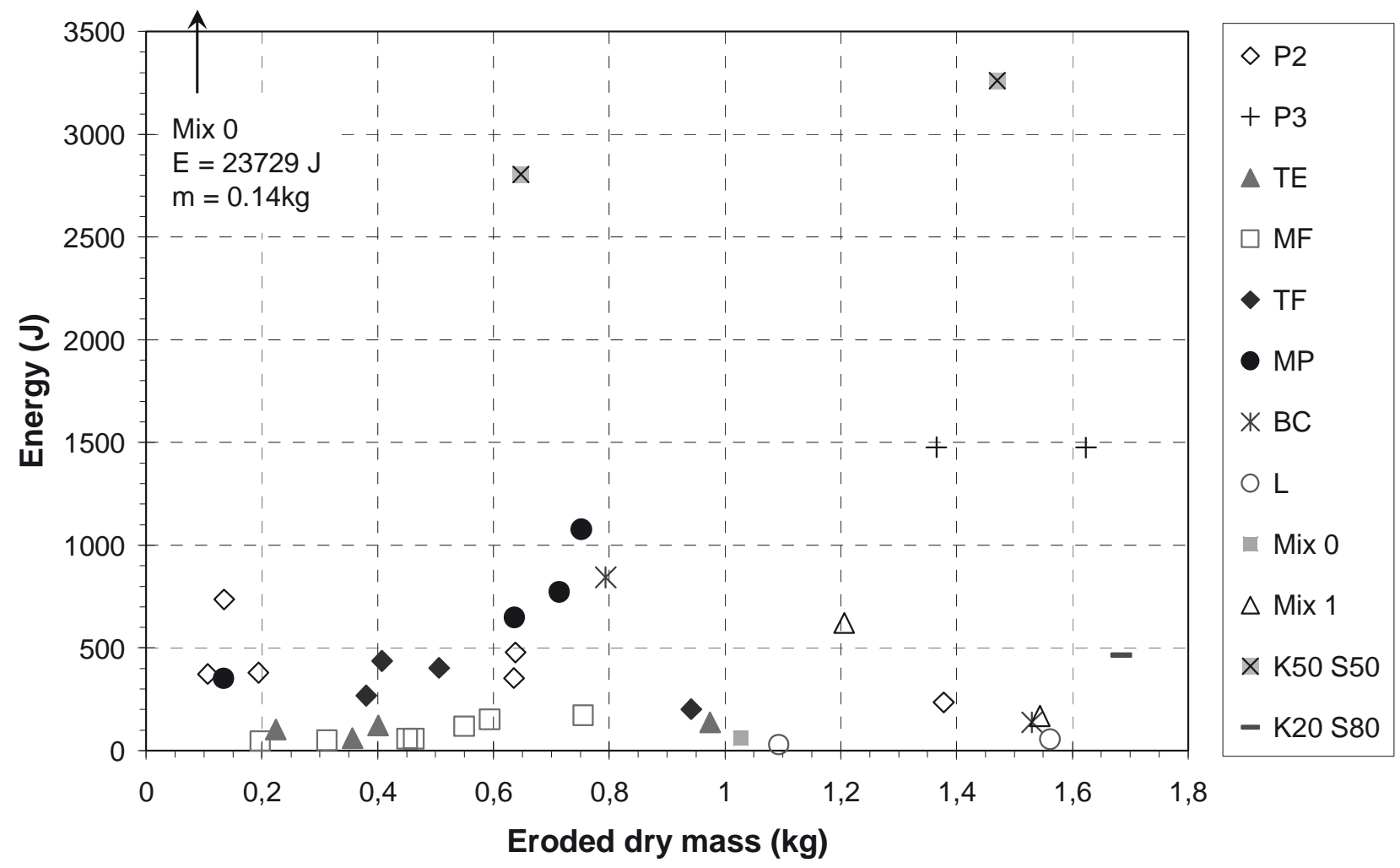

Figure 5. Energy in function of eroded dry mass

With the objective to consider the kinetic of erosion development, Figure 5 shows the energy dissipated by fluid flow in function of the cumulative eroded dry mass. The value of expended energy was between $29 \mathrm{~J}$ to $23729 \mathrm{~J}$ and cumulative eroded dry mass varied between $0.106 \mathrm{~kg}$ and $1.685 \mathrm{~kg}$.

As shown on Table 3, obtained values of erosion resistance index $I_{\alpha}$ are between 1.42 and 5.22. This great range of values may be due to the great variability of tested soils.

According to the values of $\mathrm{I}_{\alpha}$ index and Marot et al. (2011)'s classification: $\mathrm{L}$ soil is erodible, MF, TE, Mix1 and K20 S80 are moderately erodible, TF, P3 and P2 appear moderately erodible to moderately resistant, MP and K50 S50 are moderately resistant. Relatively to the others soils, the great variability of Mix 0 and $\mathrm{BC}$ does not allow to classify them precisely. It is shown that for Mix0 soil, water content discrepancy of $4 \%$ is sufficient to induce a variation of soil erodibility from highly resistant to erodible. With a water content discrepancy of $3 \%$, BC can vary between moderately resistant to erodible. 


\begin{tabular}{ccccccc}
\hline Sample & $\begin{array}{c}\text { Water content } \\
\text { at compaction } \\
(\%)\end{array}$ & $\begin{array}{c}\text { Initial } \\
\text { dry mass } \\
(\mathrm{kg})\end{array}$ & $\begin{array}{c}\text { Eroded } \\
\text { dry mass } \\
(\mathrm{kg})\end{array}$ & $\begin{array}{c}\text { Energy } \\
(\mathrm{J})\end{array}$ & $\begin{array}{c}\text { Erosion } \\
\text { resistance } \\
\text { index I } \boldsymbol{\alpha}\end{array}$ & Classification \\
\hline P2-1 & 17 & 1.650 & 0.194 & 380 & 3.29 & Mod. resistant \\
P2-2 & 13 & 1.775 & 0.106 & 372 & 3.54 & Mod. resistant \\
P2-3 & 15 & 1.701 & 0.638 & 478 & 2.87 & Mod. erodible \\
P2-4 & 16 & 1.691 & 0.635 & 352 & 2.74 & Mod. erodible \\
P2-5 & 13 & 1.774 & 0.135 & 736 & 3.74 & Mod. resistant \\
P2-6 & 12 & 1.730 & 1.378 & 234 & 2.23 & Mod. erodible \\
P3-1 & 12 & 1.742 & 1.365 & 1477 & 3.03 & Mod. resistant \\
P3-2 & 12 & 1.730 & 1.624 & 1475 & 2.96 & Mod. erodible \\
TE-1 & 16 & 1.609 & 0.224 & 102 & 2.66 & Mod. erodible \\
TE-2 & 17 & 1.611 & 0.401 & 123 & 2.49 & Mod. erodible \\
TE-3 & 16 & 1.609 & 0.356 & 61 & 2.23 & Mod. erodible \\
TE-4 & 16 & 1.607 & 0.974 & 139 & 2.15 & Mod. erodible \\
MF-1 & 14 & 1.682 & 0.550 & 118 & 2.33 & Mod. erodible \\
MF-2 & 15 & 1.685 & 0.451 & 58 & 2.11 & Mod. erodible \\
MF-3 & 14 & 1.688 & 0.594 & 150 & 2.40 & Mod. erodible \\
MF-4 & 15 & 1.662 & 0.462 & 58 & 2.10 & Mod. erodible \\
MF-5 & 15 & 1.683 & 0.312 & 51 & 2.21 & Mod. erodible \\
MF-6 & 15 & 1.689 & 0.197 & 46 & 2.37 & Mod. erodible \\
MF-7 & 14 & 1.682 & 0.755 & 171 & 2.36 & Mod. erodible \\
TF-1 & 17 & 1.571 & 0.380 & 268 & 2.85 & Mod. erodible \\
TF-2 & 18 & 1.498 & 0.407 & 437 & 3.03 & Mod. resistant \\
TF-3 & 17 & 1.518 & 0.506 & 403 & 2.90 & Mod. erodible \\
TF-4 & 18 & 1.427 & 0.941 & 201 & 2.33 & Mod. erodible \\
MP-1 & 18 & 1.564 & 0.134 & 352 & 3.42 & Mod. resistant \\
MP-2 & 17 & 1.590 & 0.636 & 649 & 3.01 & Mod. resistant \\
MP-3 & 18 & 1.512 & 0.752 & 1077 & 3.16 & Mod. resistant \\
MP-4 & 19 & 1.567 & 0.714 & 773 & 3.03 & Mod. resistant \\
& 26 & 1.263 & 0.629 & 844 & 3.13 & Mod. resistant
\end{tabular}




\begin{tabular}{|c|c|c|c|c|c|c|}
\hline Sample & $\begin{array}{c}\text { Water content } \\
\text { at compaction } \\
(\%)\end{array}$ & $\begin{array}{c}\text { Initial } \\
\text { dry mass } \\
\quad(\mathrm{kg})\end{array}$ & $\begin{array}{c}\text { Eroded } \\
\text { dry mass } \\
\quad(\mathrm{kg})\end{array}$ & $\begin{array}{c}\text { Energy } \\
(\mathrm{J})\end{array}$ & $\begin{array}{l}\text { Erosion } \\
\text { resistance } \\
\text { index } \mathbf{I}_{\alpha}\end{array}$ & Classification $^{\mathbf{a}}$ \\
\hline $\mathrm{BC}-2$ & 23 & 1.306 & 1.242 & 119 & 1.98 & Erodible \\
\hline L-1 & 19 & 1.583 & 1.562 & 55 & 1.55 & Erodible \\
\hline L-2 & 19 & 1.579 & 1.093 & 29 & 1.42 & Erodible \\
\hline $\begin{array}{c}\text { Mix } 0- \\
1\end{array}$ & 19 & 1.528 & 1.027 & 61 & 1.77 & Erodible \\
\hline $\begin{array}{l}\text { Mix 0- } \\
\quad 2\end{array}$ & 23 & 1.541 & 0.144 & 23729 & 5.22 & High. resistant \\
\hline $\begin{array}{c}\text { Mix 1- } \\
1\end{array}$ & 20 & 1.564 & 1.543 & 168 & 2.04 & Mod. erodible \\
\hline $\begin{array}{l}\text { Mix 1- } \\
2\end{array}$ & 22 & 1.540 & 1.206 & 621 & 2.71 & Mod. erodible \\
\hline $\begin{array}{c}\text { K50 } \\
\text { S50-1 }\end{array}$ & 14 & 1.678 & 1.470 & 3262 & 3.35 & Mod. resistant \\
\hline $\begin{array}{c}\text { K50 } \\
\text { S50-2 }\end{array}$ & 16 & 1.679 & 0.647 & 2805 & 3.64 & Mod. resistant \\
\hline $\begin{array}{l}\text { K20 } \\
\text { S } 80\end{array}$ & 10 & 1.861 & 1.685 & 465 & 2.44 & Mod. erodible \\
\hline
\end{tabular}

${ }^{a}$ Classification according Marot et al. (2011) soil erodibility system.

\section{Estimation of erosion resistance index from other soil properties}

\subsection{Systematic approach and existing correlation}

It is useful to estimate soil erodibility by physical parameters that may be easily measured. Analyse of correlation coefficient for each relation between physical parameter and erosion resistance index $\mathrm{I}_{\alpha}$ shows that no physical parameter allows estimating $\mathrm{I}_{\alpha}$ index. This lack of correlation may be due to the great variability of tested soils.

Based on a parametric study on 98 sets of test data, Wan and Fell (2004) proposed a correlation between erosion rate index determined by HET and nine physical parameters which was expressed for fine grained soils by:

$$
\begin{aligned}
& I_{\text {HET }}=-10.200+0.010 \quad \rho_{d}-0.042 \frac{\rho_{d}}{\rho_{d \text { opt }}}+0.100 w \\
& +0.010 \Delta w_{R}-0.006 \text { Fines }+0.042 \text { Clay }-0.090 w_{L}+0.110 \quad I_{P}+0.440 \text { Pin Hole }
\end{aligned}
$$


where $\rho_{\mathrm{d}}$ : dry density of the soil in $\mathrm{kg} / \mathrm{m}^{3}, \rho_{\mathrm{d}} / \rho_{\mathrm{d} \text { opt }}$ : percentage compaction in percent, w: water content at compaction in percent, Fines: mass fraction of fine particles in percent $(\mathrm{d} \leq 0.075 \mathrm{~mm})$, Clay: mass fraction of clay in percent $(\mathrm{d} \leq 0.005 \mathrm{~mm}), \mathrm{w}_{\mathrm{L}}$ : liquid limit in percent, $\mathrm{I}_{\mathrm{P}}$ : plasticity index in percent, PinHole: pin hole test classification (between 1 (D1) and 6 (ND1)), and $\Delta \mathrm{w}_{\mathrm{R}}$ : water content ratio in percent expressed by:

$$
\Delta w_{R}=\frac{w-w_{o p t}}{w_{o p t}}
$$

where $\mathrm{w}_{\mathrm{opt}}$ : water content at Proctor optimum.

The coefficient for the correlation [13] was 0.73 .

According to the value of pin hole test classification and the value of its associated coefficient in Equation [13], this term contributes significantly to the correlation. This contribution may be due to the physical principle of pin hole test which is similar to the HET.

For the 38 sets of test data performed by the authors, a research of predictive equation was realized by the mean of Xlstat software. Without the contribution of pin hole test value a new predictive equation for the erosion resistance index is proposed:

$$
\begin{aligned}
& I_{\alpha}=-6.020+0.012 \rho_{d}-0.164 \frac{\rho_{d}}{\rho_{d \text { opt }}}+0.307 w \\
& -0.009 \Delta w_{R}-0.013 \text { Fines }-0.010 F_{\text {clay }}+0.065 w_{L}-0.029 I_{P}
\end{aligned}
$$

The obtained correlation coefficient $\left(\mathrm{R}^{2}\right)$ is 0.64 , for a sample size $\mathrm{N}=38$.

Five terms contribute to Equation [13] and Equation [15] with the same sign (constant, $\rho_{\mathrm{d}}, \rho_{\mathrm{d}} / \rho_{\mathrm{d} \text { opt }}, \mathrm{w}$, Fines) but others parameters contribute with opposite sign to the correlations. Because of the coupling between several parameters, it is difficult to evaluate the contribution of each parameter and to reduce the number of parameters.

It can be noted that in predictive Equations [13] and [15] contribution of soil density appears two times but the influence of saturation ratio is not taken into account. That may be a reason of the weakness of correlation coefficient in spite of size of eight or nine parameters. 


\subsection{Reduction of physical parameters number by statistical analysis}

\subsubsection{Definition of used parameters}

The used parameters for the statistical analysis try to represent the soil in several characteristics. The first characteristic considers the grain size distribution. The size curve distribution is introduced by considering the clay fraction of the soil $\mathrm{F}_{\text {clay }}$, the silts fraction $F_{\text {silt, }}$, the fine sand fraction $F_{f s}$ and the coarse sand fraction $F_{c s}$. The characterization is completed by the Atterberg limits on the soil fraction below $425 \mu \mathrm{m}$. With the objective to take into account presence of fluid phases in soil, the water content, $\mathrm{w}$, and the saturation ratio $\mathrm{S}_{\mathrm{r}}$ (in percent) are considered. To describe the soil structure, the compaction, $\mathrm{c}$, and the dry densities are considered:

$$
c=\frac{\rho_{d}}{\rho_{S}}
$$

where $\rho_{\mathrm{d}}$ : dry density of the soil; $\rho_{\mathrm{s}}$ : solid density.

To represent the interaction between clay and water, the clay water content is introduced:

$$
\mathrm{W}_{\text {clay }}=\frac{\mathrm{w}}{\mathrm{F}_{\text {clay }}}
$$

Two parameters linking the Atterberg limits to the clay water content are defined:

$$
\begin{aligned}
& \Delta \mathrm{w}_{\mathrm{L}}=\mathrm{w}_{\mathrm{L}}-\mathrm{w}_{\text {clay }} \\
& \Delta \mathrm{w}_{\mathrm{P}}=\mathrm{w}_{\text {clay }}-\mathrm{w}_{\mathrm{P}}
\end{aligned}
$$

where $\mathrm{w}_{\mathrm{L}}$ : liquid limit and $\mathrm{w}_{\mathrm{P}}$ : plastic limit.

With the objective to represent the soil water exchange, the surface exchange $S_{d}$ is defined by:

$$
S_{d}=6 \sum \frac{1}{d_{50, X i}} p_{i} c
$$

where $\mathrm{d}_{50, \mathrm{Xi}}$ : average diameter of the considered fraction. For clay fraction, we consider $2 \mu \mathrm{m}$, for sand and silt fractions, average diameter is computed with grain size distribution. $\mathrm{p}_{\mathrm{i}}$ : percentage in composition of the considered fraction. 


\subsubsection{Principle of statistical analysis}

Multivariate analysis allows the full set of variables related to the measurements to be reduced to a subset representing the principal components assuming a linear correlation between the variables. Each parameter is represented in a factor space, and the geometrical representation associates a vector to each parameter. The scalar product of two associated vectors is equal to the correlation coefficient of the two parameters. An automatic classification is used to define all variables according to the most useful factors. Figure 6 shows the variables in two first factor planes.

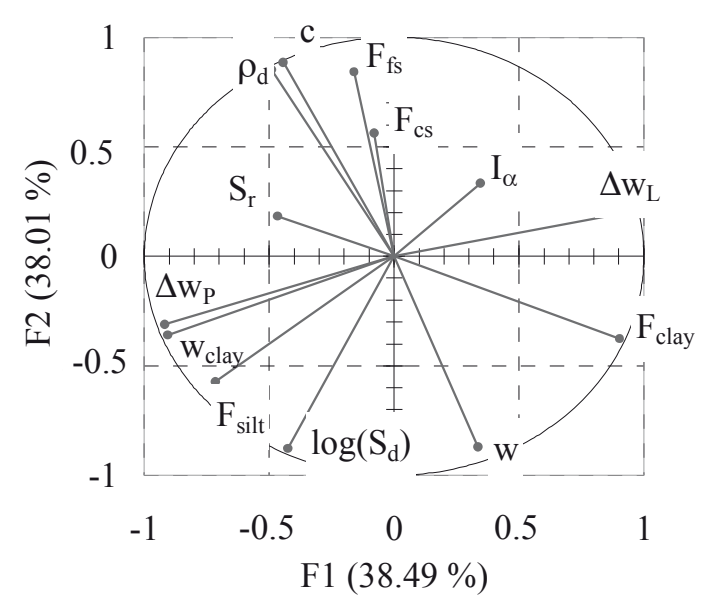

(a)

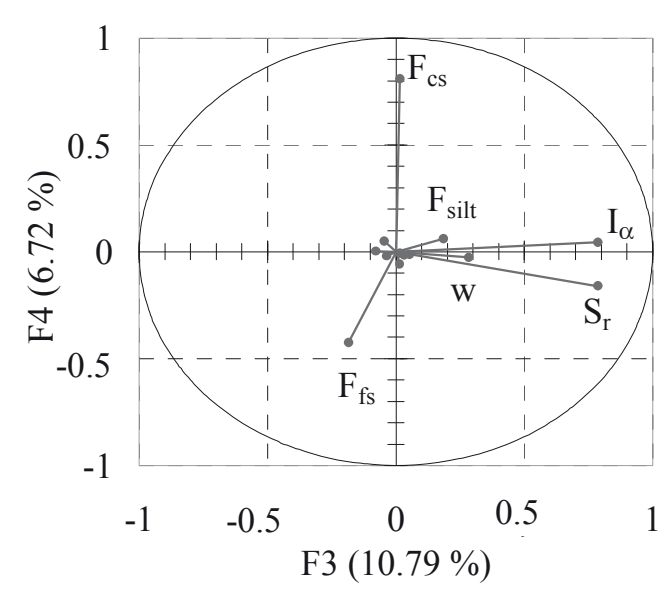

(b)

Figure 6. Variables representation in: (a) factor plane 1-2; (b) factor plane 3-4

Thus in each plan, two variables are in linear relationship when their positions are near the unit circle, and very close to each other or diametrically opposite (for example on Figure 5a: variables $\rho_{\mathrm{d}}$, $\mathrm{c}$ and $\mathrm{w}$ or $\Delta \mathrm{w}_{\mathrm{L}}, \Delta \mathrm{w}_{\mathrm{P}}$ and $\mathrm{w}_{\text {clay }}$ ). Two variables are independent when their representations are in quadrature (for example: variables $\mathrm{F}_{\text {clay }}$ and $\log \left(\mathrm{S}_{\mathrm{d}}\right)$ on Figure $6 \mathrm{a}, \mathrm{F}_{\mathrm{cs}}$ and $\mathrm{I}_{\alpha}$ on Figure $\left.6 \mathrm{~b}\right)$.

\subsubsection{Results of statistical analysis}

Now, we are eliminating the variables which are correlated, or seem meaningless by their redundancy information with other variables.

By leading a new multivariate analysis, three parameters are kept and the correlation with erosion resistance index is:

$$
I_{\alpha}=-0.97+0.47 \Delta_{w_{L}}-0.36 c+5.41 S_{r}
$$

The obtained correlation coefficient $\left(\mathrm{R}^{2}\right)$ between the prediction and the measurement is 0.35 with $\mathrm{N}=38$. By observing the distribution of the error (cf. Figure 7), it appears that the problematic soils are represented by MF, Mix 0, 
Mix 1. These soils are dispersive (Regazzoni, 2009), therefore we take into account the dispersive property of the soils.

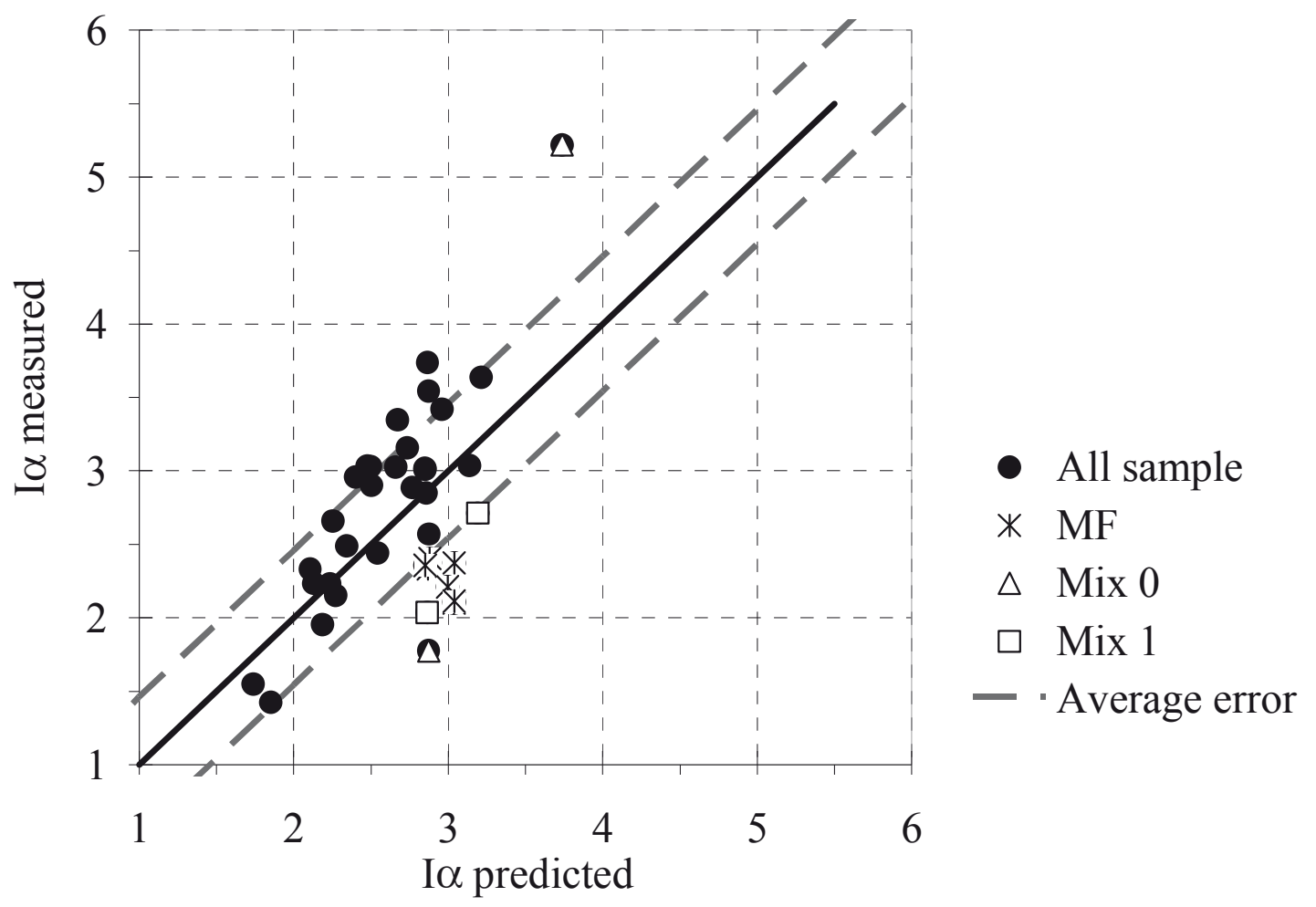

Figure 7. Erosion resistance index, measured values vs predicted values

A new correlation is defined for non-dispersive soils:

$$
I_{\alpha}=-2.31+0.69 \Delta_{w_{L}}+1.41 c+6.07 S_{r} \quad\left(\mathrm{R}^{2}=0.59, \mathrm{~N}=27\right)
$$

For the dispersive soils the expression of estimated value of $\mathrm{I}_{\alpha}$ is:

$$
I_{\alpha}=-1.36+8.69 \Delta_{w_{L}}+2.68 c+2.08 S_{r} \quad\left(\mathrm{R}^{2}=0.81, \mathrm{~N}=11\right)
$$

By distinguishing between dispersive and non-dispersive soils, we identify the main parameters for a soil analysis in relation to the surface erosion phenomenon. These main physical parameters which take into account the influence of each phase (solid, water and gas) and the influence of soil plasticity are: compaction, saturation ratio and difference between clay water content and liquid limit.

\section{Conclusion}

A Jet Erosion Test device is used in order to characterize the sensitivity to erosion of twelve fine soils which cover a large part of the Atterberg limits diagram. 
The tested samples are compacted with the standard Proctor procedure at optimum water content less $1 \%$. Study of energy exchanges between fluid and soil leads to propose a new analysis of Jet Erosion Test and a new erosion resistance index is defined. In contrast to the precedent models based on stress, the energy model leads to a same classification of soil surface erodibility for two types of apparatus: Jet Erosion Test and Hole Erosion Test (Marot et al., 2011).

Several physical parameters are determined and a statistical analysis is performed in order to identify the main parameters for a correlation with erosion resistance index.

By distinguishing the dispersive behaviour from non-dispersive behaviour, the multivariate statistical analysis leads to an expression of the erosion resistance index as a function of three physical parameters: compaction, saturation ratio and difference between clay water content and liquid limit. These parameters take into account the influence of each phase and the influence of soil plasticity. Thus, this method allows reducing the number of variables for the description of the erosion sensitivity.

It is shown that for Mix 0 soil, water content discrepancy of $4 \%$ is sufficient to induce a variation of soil erodibility from highly resistant to erodible. Thus the use of predictive equation for real structure needs to take into account the soil heterogeneities and the composition of pore and eroding fluid.

\section{Acknowledgement}

The authors wish to acknowledge Electricité de France (EDF-CIH) for the funding of the work and for their advice.

\section{References}

Beltaos S., Rajaratnam. N., "Impinging circular turbulent jets", Journal of the Hydraulics Division, HY10, 1974, p. 1313-1328.

Bonelli S, Brivois O., "The scaling law in the hole erosion test with a constant pressure drop", International Journal for Numerical and Analytical Methods in Geomechanics, vol. $32, \mathrm{n}^{\circ} 13,2008$, p. 157-1595.

Fell, R., Fry J.J., Internal erosion of dams and their foundations, Editors, Taylor \& Francis Publisher, 2007.

Foster M., Fell R., Spannagle M., "The statistics of embankment dam failures and accidents", Canadian Geotechnical Journal, vol. 37, 2000, p. 1000-1024.

Hanson G.J, Simon A., "Erodibility of cohesive streambeds in the loess area of the Midwestern USA", Hydrological Processes, vol. 15, n 1, 2001, p. 23-38. 
Hanson G. J., Cook K. R., "Apparatus, Tests procedures, and analytical methods to measure soil erodibility in-situ", Applied Engineering in Agriculture, vol. 20, n 4, 2004, p. 455462.

Marot D., Regazzoni P.L., Wahl T., "An energy based method for providing soil surface erodibility rankings", Journal of Geotechnical and Geoenvironmental Engineering, in press, available on the journal's web site.

Regazzoni P.-L., Marot D., Wahl T., Hanson G. J., Courivaud J.-R., "Soils erodibility: a comparison between the Jet Erosion Test and the Hole Erosion Test", Proc. Inaugural International Mechanics Institute (EM08), Conference (A.S.C.E.), Minneapolis, USA, 1821 May 2008.

Regazzoni P.-L., Confrontation et analyse d'érodimètres et caractérisation de la sensibilité à l'érosion d'interface. PhD thesis, université de Nantes, 2009.

USBR, United States Department of the Interior Bureau of Reclamations, "Design of small dams", Water Resources Technical Publication, 1987.

Wan C. F., Fell R., "Investigation of rate of erosion of soils in embankment dams", Journal of Geotechnical and Geoenvironmental Engineering, vol. 130, n 4, 2004, p. 373-380. 